3. Simon Maltais, Reda Ibrahim, Arsène-Joseph Basmadjian. Postinfarction Ventricular Septal Defects: Towards a New Treatment Algorithm? The Annals of Thoracic Surgery. 2009. Vol. 87. № 3. P. 687-93.

4. Poulsen S.H., Praestholm M., Munk K. Ventricular septal rupture complicating acute myocardial infarction: clinical characteristics and contemporary outcome. The Annals of Thoracic Surgery. 2008. Vol. 85. P. 1591-1596.

5. Papadopoulos N., Moritz A., Dzemali O. Long-term results after surgical repair of postinfarction ventricular septal rupture by infarct exclusion technique. The Annals of Thoracic Surgery. 2009. Vol. 87. № 5. P. 1421-1425.

6. Виноградов А. В., Чекарева Г. А., Арутюнов Г. П. Динамика развития очага некроза по данным определения активности фракции МВ КФК и прекардиального картирования. Кардиология. 1981. № 9. C. 14-17.

7. Jones B.M., Kapadia S.R., Smedira N.G. Ventricular septal rupture complicating acute myocardial infarction: a contemporary review. European Heart Journal. 2014. Vol. 35. P. 2060-2068.

DOI https://doi.org/10.30525/978-9934-26-038-4-3

\title{
ЗМІНИ ПСИХОЕМОЦІЙНОГО СТАТУСУ У ПАЦІЕНТІВ 3 ОЖИРІННЯМ ПІД ВПЛИВОМ ЗАСОБІВ ФІЗИЧНОЇ ТЕРАПІЇ
}

\author{
Аравіцька М. Г. \\ кандидат медичних наук, дочент, \\ доиент кафедри фізичної терапії, ерготерапії \\ Прикарпатський національний університет імені Василя Стефаника \\ м. Івано-Франківськ, Украӥна
}

Вступ. Психологічні та психопатологічні фактори відіграють велику роль у генезі ожиріння. Серед них особлива увага приділяється психічному стресу, емоційним та когнітивним порушенням, аномаліям особистості, розладам харчової та соціально зумовленим стереотипам поведінки [2, с. 252]. У хворих з індексом маси тіла $>25$ кг/м² зростає ризик виявлення психопатологічних розладів, а у більш ніж у половини пацієнтів $з$ морбідним ожирінням (МО) виявляються психічні порушення [4, c. 162]. 
Можливі психологічні механізми зв'язку ожиріння і депресивних розладів включають стигматизацію осіб з ожирінням, розвиток у них низької самооцінки, негативного ставлення до образу власного «Я» i подальшої тривоги та депресії. Симптоми останніх у огрядних осіб наростають паралельно збільшенню бала психосоціальних проблем. Психопатологічний дистрес виявляється у $26 \%$ осіб з ожирінням і погіршує якість життя достовірно більше, ніж супутні ожирінню соматичні захворювання [3, с. 1568-1572].

Метою дослідження було визначення ефективності програми немедикаментозної реабілітації за динамікою ознак депресії у жінок та чоловіків з ожирінням I-III ступеня.

Матеріал та методи дослідження. У процесі дослідження проведено розпитування 288 осіб другого зрілого віку (39,6 61,4 років) з екзогенним ожирінням: I ступеня - 65 жінок, 51 чоловік; II ступеня 64 жінки, 43 чоловіка; III ступеня - 43 жінки, 31 чоловік. Контрольну групу (КГ) склали 34 жінки та 26 чоловіків 3 нормальною масою тіла $(41,1 \pm 2,3$ років). За результатами попереднього визначення реабілітаційного комплаєнсу (згоди на виконання реабілітаційних рекомендацій) [1, с. 263-265] пацієнтів було поділено на дві частини. Групу порівняння (ГП, відповідно до ступеня ожиріння ГП1, ГП2, ГП3) склали особи 3 низьким рівнем комплаєнсу; вони не проходили програму реабілітації для зменшення маси тіла, але були проінформовані про ускладнення ожиріння; ознайомлені з основними принципами гіпокалорійного харчування та фізичної активності при ожирінні. Основну групу (ОГ, відповідно до ступеня ожиріння ОГ1, ОГ2, ОГЗ) склали особи з високим рівнем комплаєнсу, вони проходили річну розроблену програму корекції маси тіла із застосуванням заходів для підтримки досягнутого рівня комплаєнсу, модифікації харчування, збільшення побутової та тренувальної фізичної активності, лімфодренажних процедур, елементів поведінкової психокорекції.

Для оцінки симптомів депресії використовували Опитувальник пацієнта про стан здоров'я PHQ-9 (Patient Health Questionnaire-9) [9].

Результати дослідження. При визначенні вихідного рівня депресії у пацієнтів $з$ ожирінням виявлено наступні закономірності. Як у чоловіків, так і у жінок з ожирінням I ступеня виявлено розлади по типу легкої субклінічної депресії (рис. 1, 2). 


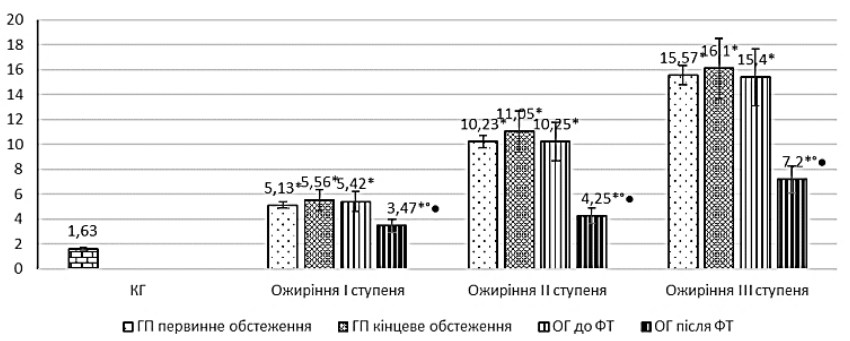

\section{Рис. 1. Динамка самооцінки ступеня депресії у чоловіків з ожирінням за PHQ-9, бали}

Примітки: * - статистично значуща різниця у порівнянні із значенням відповідного показника КГ ( $<0,05)$; - статистично значуща різнищя у порівнянні із відповідним показником до ФТ $(p<0,05)$; - статистично значуща різниця у порівнянні із відповідним показником ГП $(p<0,05)$.

Якщо за абсолютними цифровими параметрами вираженості змін пригніченого стану між гендерними групами не виявлено різниці ( $>>0,05)$, то за ступенем самооцінки впливу симптомів депресії на соціальне функціонування тільки чверть розпитаних чоловіків відмічали деякий вплив; серед жінок це відмічало більше $40 \%$.

При ожирінні II ступеня ступінь виявлених ознак відповідав депресії помірної тяжкості в обох гендерних групах, але був більше виражений у жінок, ніж у чоловіків (рис. 1,2$)(\mathrm{p}<0,05)$. Також жінки виявляли більший ступінь впливу ознак ожиріння на соціальне функціонування.

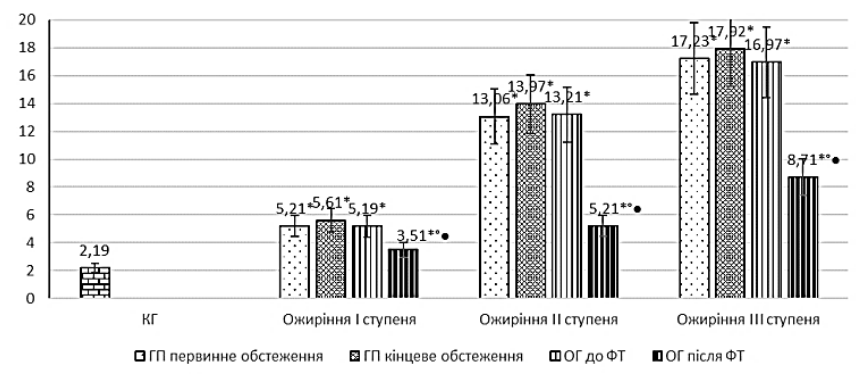

\section{Рис. 2. Динамка самооцінки ступеня депресії}

\section{у жінок з ожирінням за PHQ-9, бали}

Примітки: * - статистично значуща різниця у порівнянні із значенням відповідного показника КГ ( $<<0,05)$; - статистично значуща різниця у порівнянні із відповідним показником до ФТ $(p<0,05)$; - статистично значуща різничя у порівнянні із відповідним показником ГП $(p<0,05)$. 
У хворих з морбідним ожирінням (III ступеня) в обох статевих групах визначено зміни на рівні депресії середньої важкості. Жінки частіше, ніж чоловіки, відзначали надзвичайний вплив пригніченого настрою на соціальне функціонування.

Після проведеної програми ФТ в обох гендерних групах ОГ1 досягнуто статистично значущого покращення психоемоційного стану, що проявлялось рівнем відсутності ознак депресії. Майже всі обстежені вважали, що мінімальні ознаки психоемоційного пригнічення не впливали на психо-соціальне функціонування.

Після проведеного втручання у пацієнтів з ожирінням II ступеня параметри чоловіків статистично значуще зменшились відносно вихідного рівня та досягли рівня норми, а у жінок виявили аналогічну тенденцію, проте зупинились на нижній межі субклінічної депресії (рис. 1, 2). Цей факт базувався на тому, що вони частіше відмічали деякий вплив пригніченого настрою на функціонування, ніж чоловіки.

Під впливом програми немедикаментозної корекції у хворих з ожирінням III ступеня психо-емоційний стан статистично значуще покращився до рівня параметрів субклінічної депресії (рис. 1, 2). Але жінки, на відміну від чоловіків, як і при ожирінні II ступеня, виявляли більш виражений вплив ознак депресії на соціальні функції.

Висновки. У пацієнтів із ожирінням виявляється депресія, пропорційна ступеню ожиріння, яка більше виражена у жінок порівняно із чоловіками. Застосування немедикаментозних заходів з метою нормалізації маси тіла в рамках програми фізичної терапії призводить до зменшення ступеня психоемоційної напруги, що проявляється статистично значущим зменшенням ступеня вираженості ознак депресії при всіх ступенях ожиріння та покращення психосоціального функціонування i, відповідно покращенням якості життя.

\section{Література:}

1. Аравіцька М.Г. Аналіз індивідуальних шляхів покращення комплаєнсу хворих ожирінням як аспект визначення цілей реабілітації. Украӥнський журнал медииини, біології та спорту. 2019. Том 4. № 6 (22). 362-369 DOI: 10.26693/jmbs04.06.362

2. Carpenter KM, Hasin DS, Faith MS, Allison KS. Relationships between obesity and DSM-IV major depressive disorder, suicide ideation, and suicide attempts: results from a general population study. Am J Public Health. 2000. 090(2). 251-257. DOI: 10.2105/ajph.90.2.251

3. Cefalu WT, Bray GA, Home PD, Garvey WT, Klein S, Pi-Sunyer FX., et al. Advances in the Science, Treatment, and Prevention of the Disease of Obesity: Reflections From a Diabetes Care Editors' Expert Forum. Diabetes Care. 2015. 38(8). 1567-1582. 
4. Doll HA, Petersen SE, Stewart-Brown SL. Obesity and physical and emotional well-being: associations between body mass index, chronic illness, and the physical and mental components of the SF-36 questionnaire. Obesity Research. 2000. 8. 160-170. DOI: 10.1038/oby.2000.17

DOI https://doi.org/10.30525/978-9934-26-038-4-4

\title{
CLINICAL FEATURES OF CORONAVIRUS DISEASE IN HOSPITALIZED PATIENTS
}

\author{
Afanasiuk O. I. \\ Ph. D. in Medicine, \\ Associate Professor at the Department of Internal Medicine № 3 \\ National Pirogov Memorial Medical University \\ Shmaliy V. I. \\ Ph. D. in Medicine, \\ Associate Professor at the Department of Internal Medicine № 3 \\ National Pirogov Memorial Medical University

\section{Shushkovska Yu. Yu.} \\ Ph. D. Applicant at the Department of Internal Medicine № 3 \\ National Pirogov Memorial Medical University \\ Vinnytsya, Ukraine
}

Coronavirus disease (CVD) is an acute respiratory infection caused by the severe acute respiratory syndrome virus 2 (SARS-CoV-2). The virus was identified as the cause of an outbreak of pneumonia of unknown origin in China, Wuhan City, Hubei Province, in December 2019. The clinical picture corresponds to a respiratory infection with varying severity of symptoms from a mild cold-like illness to severe viral pneumonia, leading to potentially fatal acute respiratory distress syndrome [1, p. 41]. Given the fact that humanity first encountered the manifestations of this need, the novelty of the clinic, diagnosis, continues research to study the peculiarities of the disease in different categories of people.

The aim is to study the clinical features of coronavirus infection in severe patients who remain in hospital.

Material and methods. Criteria for inclusion in the study: diagnosed with CVD by polymerase chain reaction, hospitalization for the introduction of 